\title{
Bridging crossroads to improve patient outcomes
}

7 he practice of neurology has steadily progressed from heavy reliance on evidencebased guidelines to a close examination of personalized medicine. The traditional

bedside examination has been augmented by improved imaging, availability of big data, and discovery of disease biomarkers. The many crossroads encountered in neurology practice are addressed in this issue of Neurology ${ }^{\circledR}$ Clinical Practice.

Collaborative and integrated research among subspecialists may increase our collective knowledge about pathogenic origins and pathophysiologic mechanisms of disorders. Erro et al. (p. 138) review epidemiologic and clinical features of psychogenic nonepileptic seizures and psychogenic movement disorders to examine whether a common framework for these disorders may exist. Mosti et al. (p. 129) offer a practical guide to evaluating sleep disturbance in concussion patients.

Comparative efficacy and outcome studies help neurologists and their patients make vital decisions about diagnostic and treatment options. Spelman et al. (p. 102) use long-term registries to compare first-line natalizumab vs interferon- $\beta$ or glatiramer acetate in relapsing-remitting multiple sclerosis. In an accompanying editorial, Fox and Cutter (p. 97) discuss the limitations of answering tough questions with big data. Yaghi et al. (p. 157) examine triaging, disposition, and outcome in minor ischemic stroke.

Neurologists work closely with colleagues, patients, and insurance companies in clinical decision-making. Josephson (p. 183) discusses transitions of care, Armstrong et al. (p. 190) promote a successful model for patient engagement, and Bourdette et al. (p. 177) detail how US health care companies may hamper personalized medicine and shared decision-making. Fogel et al. (p. 164) discuss the involvement of neurologists with patients and insurance companies in the arena of clinical exome sequencing.

As always, we welcome your feedback on this issue and invite suggestions for improving Neurology: Clinical Practice!
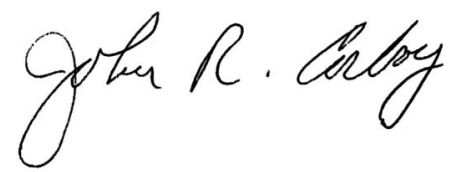

John R. Corboy, MD, FAAN 


\title{
Neurology ${ }^{\circ}$ Clinical Practice
}

\author{
Bridging crossroads to improve patient outcomes \\ Neurol Clin Pract 2016;6;95 \\ DOI 10.1212/CPJ.0000000000000241
}

This information is current as of April 4, 2016

Updated Information \& Services

Permissions \& Licensing

Reprints including high resolution figures, can be found at:

http://cp.neurology.org/content/6/2/95.full.html

Information about reproducing this article in parts (figures,tables) or in its entirety can be found online at:

http://cp.neurology.org/misc/about.xhtml\#permissions

Information about ordering reprints can be found online:

http://cp.neurology.org/misc/addir.xhtml\#reprintsus

Neurol Clin Pract is an official journal of the American Academy of Neurology. Published continuously since 2011, it is now a bimonthly with 6 issues per year. Copyright (C) 2016 American Academy of Neurology. All rights reserved. Print ISSN: 2163-0402. Online ISSN: 2163-0933.

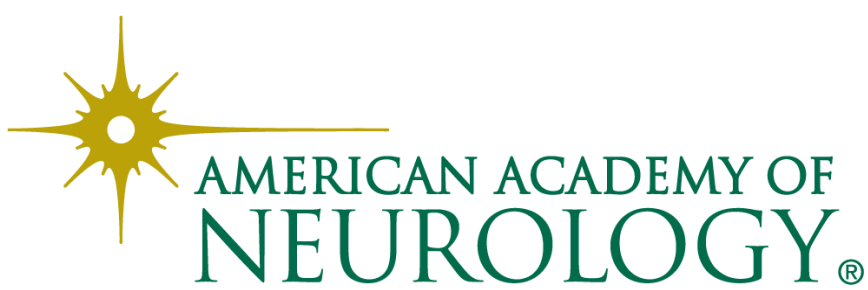

